\title{
Population dynamics and life cycle of the introduced ascidian Microcosmus squamiger in the Mediterranean Sea
}

Marc Rius ${ }^{1}$, Mari Carmen Pineda ${ }^{1}$, Xavier Turon ${ }^{2}$

${ }^{1}$ Departament de Biologia Animal (Invertebrats), Facultat de Biologia, Universitat de Barcelona. Avinguda Diagonal 645, 08028, Barcelona.

${ }^{2}$ Centre d'Estudis Avançats de Blanes (CEAB, CSIC). Accés a la Cala S. Francesc, 14, 17300 Blanes (Girona), Spain

Corresponding author: Xavier Turon

E-mail: xturon@,ceab.csic.es

Tel.: +34972336101

Fax: +34 972337806 


\begin{abstract}
Marine introductions are a serious threat for biodiversity, especially in seas where shipping is intensive. Microcosmus squamiger is a widespread marine invader that can alter native biota and it is therefore imperative to understand its biology and ecology. We studied the population dynamics and reproductive cycles of $M$. squamiger over a 2-year period, as well as its settlement and colonization patterns, in a northwestern Mediterranean (NE Spain) locality where $M$. squamiger has been introduced. All biological parameters showed a strong seasonal pattern that peaked in summer with a major spawning episode at the end of summer. Size-frequency histograms indicated a 2-year cycle. Colonization experiments suggested that $M$. squamiger recruitment mortality is high and requires a well structured community. In addition, we monitored the abundance of the native predator Thais haemastoma, which showed a significant positive correlation with $M$. squamiger biomass, indicating its potential usefulness as a biological control.
\end{abstract}

Keywords: invasive species, population dynamics, life cycle, Microcosmus squamiger, gonad index, biological control 


\section{Introduction}

Biotic invasions are one of the major threats for the maintenance of global biodiversity (Mack \& D'Antonio 1998, Mack et al. 2000). In the Mediterranean Sea, the increasing arrival of non-indigenous marine organisms through shipping, mariculture and with the opening of the Suez Canal has resulted in serious alterations of the native biota (Galil 2000, Streftaris \& Zenetos 2006). Some introductions have caused loss of biodiversity and are threatening native species (Papaconstantinou 1990, Zibrowius 1991, Galil 2000, Occhipinti Ambrogi 2000, Fine et al. 2001, Piazzi et al. 2001, Boudouresque \& Verlaque 2002, Galil 2007).

Ascidians have recently received great attention as marine invaders (Lambert 2007, Whitlatch \& Bullard 2007). They can spread through shipping (Wasson et al. 2001) and, once established, extend their range rapidly (Bullard et al. 2007) to become the dominant species (Lambert \& Lambert 2003), displacing native space occupiers (Castilla et al. 2004).

The solitary ascidian Microcosmus squamiger (order Stolidobranchia, family Pyuridae) is considered to be native to Australia (Michaelsen 1927, Kott 1985, Monniot et al. 2001) but it has been detected worldwide (Naranjo \& García-Gómez 1994, Naranjo et al. 1996, Lambert \& Lambert 1998, Monniot et al. 2001, Monniot 2002, Godwin 2003, Primo \& Vázquez 2004, Turon et al. 2007, Rius et al. 2008). In its introduced range, this species can live attached to either artificial or natural hard substrata both inside and outside of harbours (Naranjo et al. 1996). M. squamiger is currently considered a global marine invader, as it has established itself in many regions around the world where it alters local biota (Lambert \& Lambert 1998, 2003, Turon et al. 2007). In southern California, for example, the solitary ascidian Styela canopus that was previously well established in harbours, is now in decline while M. squamiger has 
increased its abundance and appears to be replacing S. canopus (Lowe 2002). In a nearby location, Bahía Falsa, this species has been found in high abundance in oyster farms, where it poses an economic threat (pers. comm. L. Rodríguez). Even in its native range this species has been found competing for space with oysters on the western (Kott 1985) and eastern (M.R. pers. obs.) Australian coasts, and in Tasmania, where it can be destructive to oysters (Kott 1985). As a result, this species must be considered as a potential threat for both the local biota and economies. In the Mediterranean Sea, $M$. squamiger was first recorded (as M. exasperatus) in the early 1960s in Bizerte, Tunisia (Monniot 1981). Since then, Mediterranean records of this species have frequently referred to it as M. exasperatus, but a taxonomic revision by Turon et al. (2007) has established the present range of M. squamiger in the Mediterranean, which covers its entire western basin (see also Mastrototaro \& Dappiano 2005).

Crucial to the establishment of an alien species as an invader is its ability to overcome local control by resident species (Osman \& Whitlatch 1998, Stachowicz et al. 2002), the adequacy of temperature and other parameters for its development (deRivera et al. 2007), and interactions with native predators (Noonburg \& Byers 2005) and local biota (Ranasinghe et al. 2005, Rodriguez 2006). Clearly, a preliminary step in the management of any invasive species is to acquire a deep knowledge of its biology and ecology; in particular, what concerns reproductive strategies, growth rates, population dynamics, and interactions with other species. Only a few studies have focused on the life cycles of introduced marine organisms in their new environment (e.g. Grosholz \& Ruiz 1996, Fine et al. 2001, Thornber et al. 2004). In the case of ascidians, although information is accumulating on biological and ecological features of solitary and colonial species (e.g. Becerro \& Turon 1992, Turon \& Becerro 1992, Giangrande et al. 1994, Eckman 1996, de Caralt et al. 2002, López-Legentil et al. 2005, Pérez-Portela et 
al. 2007), studies focussing on introduced ascidians are rare (but see Yamaguchi 1975, Parker et al. 1999, Shenkar \& Loya 2008). This type of study is crucial for understanding the colonizing processes of invasive species, as well as their establishment in the new environment and potential interactions with native species. From preliminary observations we often witnessed the muricid gastropod Thais haemastoma actively predating on $M$. squamiger by inserting its proboscis through the ascidian tunic.

In this work we studied the population dynamics of $M$. squamiger over a 2-year period in a location on the northeast coast of the Iberian Peninsula. M. squamiger is the dominant species along this stretch of coast (Turon et al. 2007), densely carpeting rocky reefs, thriving on natural and artificial rocky reefs and displacing native assemblages (authors' pers. obs.). We monitored the life cycle features of this species through analyses of its population structure and reproductive cycle, as well as its settlement and colonization patterns on bare substratum. In addition, we monitored the abundance of the predator T. haemastoma and tested its correlation with the abundance of the ascidian prey.

\section{Materials and Methods}

\section{Study site}

The study was undertaken in the outer part of the main breakwater of Cubelles $\left(41^{\circ} 11^{\prime} 37.2^{\prime \prime} \mathrm{N}, 1^{\circ} 39^{\prime} 17.46^{\prime \prime} \mathrm{E}\right)$, which was located in the north-western Mediterranean Sea, NE Spanish coast. This coastal defence structure (approximately $800 \mathrm{~m}$ long) faces southeast and is formed by concrete blocks $\left(\sim 4 \mathrm{~m}^{2}\right)$. The closest main harbour and recreational marina are situated in Tarragona (ca. $40 \mathrm{Km}$ ) and Segur de Calafell (ca. 4 $\mathrm{Km}$ ) respectively. The sea bottom is constituted by fine sand and, as a result, the only 
hard substratum available is the actual breakwater. The maximum depth is 3 meters and M. squamiger has colonized from the bottom up to a few centimetres below the surface, covering $100 \%$ of the available space in most places. In the upper level of its distribution, M. squamiger shares the available space with clumps of the mussel Mytilus galloprovincialis. Five points separated by at least $\sim 25$ meters were randomly selected along the coastal defence structure for survey sites.

\section{Fieldwork}

Surveys were done monthly from July 2005 until June 2007 using SCUBA. For the study of abundance and population structure we scraped the rocky surface at each sampling point ( $\mathrm{n}=5$ ) using a chisel. The area scraped was $18 * 12 \mathrm{~cm}$, and it was delimited by a metal frame randomly placed on the substratum. Samples were taken between 2 and $3 \mathrm{~m}$ depth at each of the five sites. Each sample was placed in a labelled plastic bag. To detect the scraped plots in subsequent surveys (see below), we marked them with a plastic label attached to a bolt with a cable tie. The bolts were driven into holes bored at one corner of the scraped area using a manual drill. The water temperature was recorded using a dive computer with $0.1^{\circ} \mathrm{C}$ of precision. In addition, we surveyed the abundance of $T$. haemastoma through randomly placing two 50x50 cm quadrats on the rock at each of the five sampling points and counting all T. haemastoma individuals in the quadrats. In order to study the reproductive cycles of M. squamiger, we randomly collected 25 fully grown individuals situated away from the sampling points. After each dive we transported the samples to the laboratory in a 201 insulated container with seawater. Transport time did not exceed 45 minutes.

In February 2006, we studied whether depth had any effect on the length and wet weight of M. squamiger populations. For this, we divided the breakwater into 3 depth 
levels (0-1 m, 1-2 $\mathrm{m}$ and 2-3 $\mathrm{m}$ ) from surface to bottom. At each of the 5 sampling points we randomly collected 5 fully grown animals per depth level.

To assess recruitment, we periodically placed settlement plates in the field. We used plastic Petri dishes (60 mm diameter, 2 dishes per site) with a hole in the centre, through which the dish was fastened to the substratum with screws. This study started in December 2005 and the dishes were removed monthly (from January to October 2006) and replaced by new ones. We systematically scrutinized each dish for the presence of M. squamiger recruits using a dissecting microscope.

The monthly scrapings provided experimental units for assessing colonization of bare substrata by M. squamiger. In March 2007 we re-scraped all sampled squares. We managed to re-scrape most squares from each sampling date, except July and November 2005 for which all labels were lost. Thus, we had a range of surfaces with different times of exposure and different seasons of initial scraping.

\section{Laboratory techniques}

Once in the laboratory the scraped material was immediately fixed using $70 \%$ ethanol. Thus, the individuals were not previously relaxed and in contact with ethanol they quickly contracted. We assumed that all individuals were similarly contracted when body measurements took place, but these do not reflect maximal sizes for this reason. During sample processing, all $M$. squamiger individuals were separated from the rest of the organisms (polychaetes, molluscs, algae and other ascidians) and sand using a $3 \mathrm{~mm}$ sieve under running freshwater. During the cleaning of M. squamiger samples, we occasionally found a similar species, Microcosmus polymorphus, which could be distinguished from M. squamiger because M. polymorphus is generally bigger, has a tougher tunic and a larger and tougher attachment base. In case of any doubt, specimens were dissected and identified following Monniot (1962). To obtain the 
abundance of $M$. squamiger, sample counts were transformed to individuals per square meter.

The tunics of M. squamiger individuals were carefully cleaned to remove any attached organisms. We then measured the body of the individuals (length, width, height and intersiphonal distance) to the nearest mm using a calliper. Subsequently, we blotted the animal on paper tissue and measured the wet weight of the whole organism. Afterwards, the ascidians were dissected, tunic and mantle separated, blotted dry and wet weighed. Finally we placed the mantle and the tunic at $60^{\circ} \mathrm{C}$ for 24 hours to obtain their dry weight. After measuring and weighing many individuals (see results), we found a highly significant positive relationship between all variables and, as the whole process was extremely time consuming, we decided to simplify the measurements of the subsequent individuals $(\mathrm{N}=1439)$ by measuring only the length and the wet weight of the entire organism. The same methodology was used for the samples taken to assess differences of M. squamiger populations at different depths and for the re-scraped samples.

The samples for the study of the reproductive cycles were preserved using $10 \%$ buffered formalin, to better preserve the internal organs. We dissected 5 individuals per month and separated the gonads from the mantle by carefully dissecting the gonad lobes under a dissecting microscope. Care was taken especially with the left gonad to avoid cutting away fragments of the gut. Subsequently, we measured the wet and dry weight of the gonads, mantle and tunic as described above. A gonad index was then calculated dividing the added dry weights of the two gonads by the mantle dry weight as described in Becerro \& Turon (1992).

In order to analyse the state of maturity of the gonads, we analysed stained sections of the gonad. For this, we dissected at least 3 individuals per sampling date and 
removed a piece of the central lobe of the right gonad $\left(\mathrm{ca} .0 .025 \mathrm{~cm}^{2}\right)$. The pieces of gonad tissue were dehydrated, embedded in paraffin, sectioned and stained with haematoxylin-eosin following standard procedures.

The gonad sections were observed under a microscope equipped with a

micrometer. We measured the diameter of oocytes (following Bingham 1997) sectioned through the nucleolus (100 oocytes whenever possible, and a minimum of 70 ). For the testes we established a categorical maturity index, following Becerro \& Turon (1992) according to five (subjective) degrees of male follicle development (i.e., $1=$ absent, $2=$ traces, $3=$ low, $4=$ medium and $5=$ high $)$.

\section{Data analysis}

Morphometric relationships were tested by the Spearman Rank Correlation coefficient, and the significance level Bonferroni-adjusted for the number of pairwise comparisons between variables made.

Temporal trends of several variables were compared among them or with temperature using cross-correlation analysis. In this analysis, the standard Pearson coefficient between variables is calculated with one variable lagged with respect to the other (time lags were in months). A correlation for a negative lag indicates the correlation of the values in the first series to values in the second series that number of months earlier. The correlation at lag 0 is the usual Pearson correlation. Similarly, correlations at positive lags relate values in the first series to subsequent values in the second series.

One-way ANOVA was performed to assess the effect of depth on the length and wet weight data from the organisms collected for this purpose in February 2006. 
Normality and homogeneity of variance of the data were tested using Shapiro-Wilk's W test and Levene's test, respectively.

We performed all analyses using the software SYSTAT (v. 11, SPSS Inc., 2004), STATISTICA (v. 6, Statsoft Inc., 2001) and SPSS (v. 12, SPSS Inc., 2003).

\section{Results}

The patterns of abundance over the study period are shown in Fig. 1a. $M$. squamiger occurs in high numbers (from ca. 500 up to ca. 2300 individuals $/ \mathrm{m}^{2}$ ) all year round. The most prominent feature observed was a decrease in abundance following the maximum temperature in July 2005 and 2006. The values of density are more erratic in the winter months, which may reflect the spatial heterogeneity of the population. Decreases in abundance were observed at the end of winter (February 2006 and 2007). Overall, an increasing trend in numbers during spring was evident in 2006, leading to a peak in July. This same increase was found in spring 2007, and the abundance values at the end of the study were the highest recorded. A cross-correlation analysis of abundance versus temperature (Fig. 2) shows that the correlation coefficient was not significant at any time lag, although the highest coefficients corresponded to a negative relationship between abundance and temperature in the preceding months (time lags of 2 and -3$)$.

We found that all morphometric variables of the individuals measured showed a significant positive correlation when paired-comparisons were made using 522 individuals from the first 13 months (Table 1). We therefore restricted further analysis to only length and wet weight. When we plotted the values of these variables over the study period (Fig. 1b), a decline in both variables after summer was apparent, with the values remaining low during winter and increasing again in spring. This pattern 
reflected a general decreasing trend from the beginning of the study (July 2005), when all variables showed the highest values, until the end of the study.

The mean values of size-related variables (length and weight) did not reflect the underlying cohort dynamics. We therefore plotted these variables in separate sizefrequency histograms per month (Fig. 3, as weight and length provided the same information, only length is shown) to elucidate the settlement period and the longevity of M. squamiger. It should be noted that the smallest size classes that could be quantified accurately in our samples were of ca. 4-5 mm.

There was a bimodal distribution apparent in the months from March to July. After that, there was a decrease in numbers in August through October associated with the disappearance of the largest mode. The remaining individuals increased in size in the following months and, in February small individuals began to become abundant, with the bimodality being restored during the following months. The overall pattern was repeated in the second year of the study. The observations are coherent with a 2-year cycle, with small individuals appearing in the samples around February-March, growing until August the following year, and disappearing in September. Each cohort coexists with the next one during some months (in its second winter), in which a bimodal distribution of size is observed. The decreasing trend observed in the mean size values (Fig. 1b) was the result of the high proportion of individuals of the younger cohort in the last months of the study. When we plotted the percentages of small $(<5 \mathrm{~mm})$ and big (>20 mm) individuals of each month (Fig. 4), the appearance of small recruits in autumn-winter, and the decline in big specimens at the end of summer was apparent.

The reproductive cycle of $M$. squamiger showed a clear annual pattern, with an important peak of the gonad index in summer and minimum values in winter and spring (Fig. 5a). In general, maximum values in summer were followed by an abrupt decrease. 
Interannual differences were also found, as in 2006 the cycle was clearly advanced with respect to 2005. The cycle of 2007 closely mirrored that of 2006. Interannual differences may be related to differences in temperature. A cross-correlation analysis of gonad index vs temperature (Fig. 6) shows a typical seasonal pattern with high similarity in the time course of both variables. Maximal correlation values were found at time lags close to 0 and negative values at time lags 5-6 months apart.

The examination of the gonad histology showed the presence of a central core of female follicles with oocytes surrounded by peripheral male follicles. The condition of the male and female gonads confirmed the time course of the reproductive cycle previously found. Both the mean oocyte diameter and the maturity state of testes (Fig. $5 b)$ indicated a reproductive event at the end of summer, followed by a non-mature state during winter and a gradual build-up of the gonads during spring. Interestingly, after the abrupt gonad index decrease of July-August 2006, both oocyte size and the maturity state of testes pointed out that gonads still remained mature until October, which suggests that after an initial spawning episode, additional gamete release events could occur over several months.

The percent of oocyte size-categories (Fig. 7) showed that oocytes of the larger size classes $(>50 \mu \mathrm{m})$ appeared in spring and were shed by the end of summer. Residual oocytes of the larger classes could be observed in December 2005 and November 2006, but generally during wintertime most of the oocytes belonged to the smallest size-classes (0-25 and 25-50 $\mu \mathrm{m})$.

The measurements of length and weight of the animals collected to test the effect of depth (0-1, 1-2, and 2-3 m depth levels) on M. squamiger populations showed nonsignificant differences between depths in both variables (1-way ANOVA, $\mathrm{F}_{2,72}=0.217$, $\mathrm{P}=0.806$, for length; and $\mathrm{F}_{2,72}=0.026, \mathrm{P}=0.974$, for wet weight). 
The surveys of the predator T. haemastoma showed that the mean density of the gastropod and the available biomass of $M$. squamiger (calculated as the product of density by wet weight) followed a similar trend (Fig. 8). Accordingly, the crosscorrelation between both variables (Fig. 9) showed a highly significant (Pearson's

$r=0.737, \mathrm{p}<0.001)$ value at time lag 0 , and the second largest correlation coefficient was between abundance of T. haemastoma and M. squamiger biomass in the preceding month (time lag -1).

A high number of scraped plots (ca. 70\%) could be located again and re-scraped in March 2007. These showed no new M. squamiger colonizers in plots sampled after July 2006. There was a trend of increasing number of individuals in older plots (Fig. 10), although the values generally remained much lower than the mean values of abundance found in the initial scrapings. Only in a plot scraped in August 2005 did the recolonization value rise to almost $90 \%$ of the original abundance. The size of the individuals (presented as length in Fig. 10) generally followed an increasing trend as we move backwards in the timing of the first scraping of the plots. In spite of this evidence of recolonization, on the settlement plates deployed monthly we could not find any $M$. squamiger recruits. The plates were colonised by a variety of other organisms (mainly algae), but the only ascidians present were a few specimens of Botryllus schlosseri.

\section{Discussion}

The introduced ascidian Microcosmus squamiger formed dense populations in the area studied, reaching up to 2300 ind $\mathrm{m}^{-2}$. Albeit with important density fluctuations, the species was present all year round and constituted the major structure-forming organism in the shallow sublittoral of this zone. Moreover, this species was found colonizing nearby natural rocky habitats in this area, although with lower densities 
(authors' pers. obs.). Its presence, therefore, has strong implications in the structure and functioning of native assemblages. In a phylogeographic study of $M$. squamiger, Rius et al. (2008) found that introduced populations of this species have a high genetic variability (possibly as a result of recurrent introductions). This species, therefore, has the potential to further expand its presence in Mediterranean sublittoral communities. The synergism arising from the combination of ecological and genetic perspectives may be crucial for the development of efficient measures to control the threats posed by invasive species (Sakai et al. 2001).

The studied species displayed a strong seasonal pattern in the biological parameters analysed. M. squamiger abundance peaked in summer months, when reproduction occurs. Old individuals died soon after and the stock was replenished by the growth of a new cohort during winter. Size and weight similarly showed a minimum after summer. The cycle of $M$. squamiger, therefore, appeared to be coupled to the seasonal variations in temperature and associated parameters (e.g. food availability, see Coma \& Ribes 2003). Interannual differences were also observed, with more individuals in 2007 than in 2005, but smaller. The size frequency histograms showed that this was due to the greater strength of the smallest cohort of individuals. The reason for these variations is unknown; perhaps it was related to a trend of increasing temperatures or inscribed in a longer cycle of changes.

Although we could not monitor individual specimens over time, the sizefrequency histograms indicated a 2-year cycle. In this cycle individuals settled as a result of the summer reproduction, grew during the next winter and spring and remained in the population until summer of the following year, disappearing thereafter. Consequently, the size structure of the population showed a bimodal distribution during some months, when the two coexisting cohorts could be discerned. This was in 
accordance with what Panagiotou et al. (2007) found with the congener Microcosmus savignyi in the Mediterranean Sea. As we have used only fully grown individuals in the gonad analyses, we cannot assess whether they were one- or two-years old. However, it seems likely that a given cohort can reproduce in the first and the second summer of its life-span. The suggested life-span of two years falls within the range indicated for other solitary ascidians, although in general life-spans can vary according to the latitudinal range in which the species are found (Millar 1971, Svane 1983). Other species of the same family (Pyuridae) can have a remarkable longevity in cold waters, e.g. Pyura tessellata on the Swedish coast (Svane \& Lundalv 1982).

The mortality of $M$. squamiger observed after summer suggests that this season was the unfavourable one, as found in other Mediterranean invertebrates (Coma et al. 2000). It was common to observe underwater carcasses (in the form of empty and decomposing tunics) of dead individuals during the months following the peak temperatures (authors' pers. obs.). In a study that assessed the fertilization success of $M$. squamiger in the laboratory at different temperatures, fertilized eggs developed normally at 20 and $25^{\circ} \mathrm{C}$, while at $30^{\circ} \mathrm{C}$ eggs failed to produce viable embryos (MR, unpubl. res.). This result and the mortality observed in the present study suggest that during extraordinary warm periods, which have been recently often observed during summer in the Mediterranean, this species' survival might be compromised.

Reproductive cycles showed a clear trend: the mean gonad weight was the highest in summer, followed by an abrupt decrease. These results are similar to those found for Halocynthia papillosa in the Mediterranean by Becerro \& Turon (1992), while the same study found that Microcosmus sabatieri reproduced later, from autumn until the beginning of winter. These results indicate that all these species have seasonal reproductive patterns. Interestingly, another pyurid species introduced in the 
Mediterranean Sea, Herdmania momus, has continuous breeding in its native range (the

Red Sea) whereas in the Mediterranean this species appears to have two short reproductive periods in spring and autumn (Shenkar \& Loya 2008).

The histological analysis of the gonads was coherent with the gonad index results and showed a single spawning season per year, although mature oocytes and sperm were found during several months (from May to September). This suggests that, although the steep decrease in gonad index clearly indicates the main gamete release episode, smaller spawning events could occur over subsequent months. Alternatively, those gametes could be simply non-spawned remains of the reproductive season to be gradually resorbed. The mean oocyte diameter and the testes' development followed the same trend, with the highest values during summer months and minimum values between November and February. Microcosmus squamiger can be considered a simultaneous hermaphrodite since both sperm and oocyte maturation and release takes place synchronously, as has been reported in many other solitary ascidians (Millar 1971, Becerro \& Turon 1992, Marshall 2002). Nevertheless, testes seemed to recover faster than oocytes after the minima in November, which indicated a slight protandry in gonad development. Some degree of protandry was also observed in a Brazilian population of Phallusia nigra (da Rocha et al. 1999).

It is surprising that we could not detect any settlers or recruits on the Petri dishes placed in the field. In a separate study, M. squamiger settlement was studied in the laboratory (MR unpubl. res.) using the same type of Petri dishes. This surface was therefore suitable for settlement and we have extensive experience with observations of both settlers and recruits of this species, so could not possibly have overlooked them. Our own data on settler growth indicate that they ranged in length from ca. $0.2 \mathrm{~mm}$ the first week to ca. $2 \mathrm{~mm}$ after 5 weeks, which should be clearly detectable. One possible 
explanation would be that the plastic surfaces are not preferred for settlement when larvae have a choice of where to settle (unlike the situation in a laboratory).

Alternatively, high mortality during the vulnerable first weeks of life could have resulted in the loss of all settlers before we could examine them.

The recolonization experiment (through re-scrapings) is consistent with high recruit mortality. The percent of recolonization was low even for plots that were scraped more than one year before the re-scraping. Significantly, plots scraped from December 2005 to October 2006 and re-scraped in March 2007 could only receive recruits from the 2006 reproduction event, yet the older plots had more recruits than the more recently scraped, and we did not detect any recruits in plots scraped from July 2006 onwards. This suggests that some level of community development is necessary for $M$. squamiger settlement or, alternatively, for avoidance of predation of juvenile specimens (the more recent plots were still essentially bare rock with filamentous algae). This, together with the lack of recruitment in the petri dishes suggests that $M$. squamiger is a secondary colonizer that needs a well structured community in order to ensure successful establishment.

We found a strong correlation between the biomass of $M$. squamiger and the density of the whelk T. haemastoma, which has already been identified as a predator of other pyurids such as Pyura praeputialis in Chile (Castilla et al. 2004). Whether this relationship responds to both species having a similar seasonal cycle or whether the abundance of $M$. squamiger enhances the population of the predator needs to be addressed with experimental work. Notwithstanding, the clear correlation found points to a potential role of the native T. haemastoma as a biological control of the introduced ascidian (see Lafferty \& Kuris 1996). T. haemastoma is known to shift feeding habits when novel types of prey are available (Rilov et al. 2002). During the surveys, we 
frequently observed T. haemastoma laying eggs in between crevices around where $M$. squamiger dominated the substrata. The gastropod itself is appreciated as a delicacy and harvested in the Spanish Mediterranean, which may make its use in pest control profitable, although clearly more research is needed about the specificity and consumption rates of the predator. Another approach could be to develop a commercial fishery of M. squamiger outside harbour areas. Some species of the genus Microcosmus are harvested as food in France (Lambert \& Lambert 1998), and related species of the genus Pyura are used as fish bait or as food in distant regions of the world (Kyle et al. 1997, Monteiro et al. 2002, Castilla et al. 2004).

The study of life cycles is particularly relevant for species that are widely distributed as a result of multiple introductions. It has been noted that such species adapt their growth and reproduction features to local conditions (particularly temperature). Several ascidian species, such as Ciona intestinalis, Styela plicata or Herdmania momus, provide clear instances of such adaptive plasticity (Yamaguchi 1975, Shenkar \& Loya 2008; see Millar 1971 for a review of earlier literature). Thus, it is not possible to extrapolate results across different parts of the distributional range, which suggests that an effective management would include the acquisition of knowledge about the biology of the organism in the geographical area concerned. Further studies are necessary to compare life history traits of M. squamiger in the native and introduced distributional ranges.

\section{Acknowledgements}

We are grateful to A. Bucci and I. Calderón for assistance in the field. We thank P.A. Maíllo and M. Durfort for their help with the histological procedures. This study was funded by project CTM2007-66635 of the Spanish Government. 


\section{References}

Becerro MA, Turon X (1992) Reproductive cycles of the ascidians Microcosmus sabatieri and Halocynthia papillosa in the northwestern Mediterranean. Mar Ecol - Evol Persp 13:363-373

Bingham BL (1997) Light cycles and gametogenesis in three temperate ascidian species. Inv Biol 116:61-70

Boudouresque CF, Verlaque M (2002) Biological pollution in the Mediterranean Sea: invasive versus introduced macrophytes. Mar Poll Bull 44:32-38

Bullard SG, Lambert G, Carman MR, Byrnes J, Whitlatch RB, Ruiz G, Miller RJ, Harris L, Valentine PC, Collie JS, Pederson J, McNaught DC, Cohen AN, Asch RG, Dijkstra J, Heinonen K (2007) The colonial ascidian Didemnum sp A: Current distribution, basic biology and potential threat to marine communities of the northeast and west coasts of North America. J Exp Mar Biol Ecol 342:99108

Castilla JC, Guiñez R, Caro AU, Ortiz V (2004) Invasion of a rocky intertidal shore by the tunicate Pyura praeputialis in the Bay of Antofagasta, Chile. Proc Nat Acad Sci USA 101:8517-8524

Coma R, Ribes M (2003) Seasonal energetic constraints in Mediterranean benthic suspension feeders: effects at different levels of ecological organization. Oikos $101: 205-215$

Coma R, Ribes M, Gili J-M, Zabala M (2000) Seasonality in coastal benthic ecosystems. TREE 15:448-453 
da Rocha RM, da Cruz Lotufo TM, de Almeida Rodrigues S (1999) The biology of Phallusia nigra Savigny, 1816 (Tunicata: Ascidiacea) in southern Brazil: spatial distribution and reproductive cycle. B Mar Sci 64:77-87

de Caralt S, López-Legentil S, Tarjuelo I, Uriz MJ, Turon X (2002) Contrasting biological traits of Clavelina lepadiformis (Ascidiacea) populations from inside and outside harbours in the western Mediterranean. Mar Ecol Prog Ser 244:125137

deRivera CE, Hitchcock NG, Teck SJ, Steves BP, Hines AH, Ruiz GM (2007) Larval development rate predicts range expansion of an introduced crab. Mar Biol $150: 1275-1288$

Eckman JE (1996) Closing the larval loop: Linking larval ecology to the population dynamics of marine benthic invertebrates. J Exp Mar Biol Ecol 200:207-237

Fine M, Zibrowius H, Loya Y (2001) Oculina patagonica: a non-lessepsian scleractinian coral invading the Mediterranean Sea. Mar Biol 138:1195-1203

Galil BS (2000) A sea under siege - alien species in the Mediterranean. Biol Inv 2:177186

Galil BS (2007) Loss or gain? Invasive aliens and biodiversity in the Mediterranean Sea. Mar Poll Bull 55:314-322

Giangrande A, Geraci S, Belmonte G (1994) Life cycle and life history diversity in marine invertebrates and the implications in community dynamics. Ocean Mar Biol 32: 305-333

Godwin LS (2003) Hull fouling of maritime vessels as a pathway for marine species invasions to the Hawaiian Islands. Proceedings of the Third International Conference on Marine Bioinvasions:1-45 
Grosholz ED, Ruiz GM (1996) Predicting the impact of introduced marine species:

lessons from the multiple invasions of the european green crab Carcinus

maenas. Biol Cons 78:59-66

Kott P (1985) The Australian Ascidiacea, Part 1. Phlebobranchia and Stolidobranchia. Mem Queensland Mus 23:1-438

Kyle R, Pearson B, Fielding PJ, Robertson WD, Birnie SL (1997) Subsistence shellfish harvesting in the Maputaland marine reserve in northern Kwazulu-Natal, South Africa: rocky shore organisms. Biol Cons 82:183-192

Lafferty KD, Kuris AM (1996) Biological control of marine pests. Ecology 77:19892000

Lambert CC, Lambert G (1998) Non-indigenous ascidians in southern California harbors and marinas. Mar Biol 130:675-688

Lambert CC, Lambert G (2003) Persistence and differential distribution of nonindigenous ascidians in harbors of the Southern California Bight. Mar Ecol Prog Ser 259:145-161

Lambert G (2007) Invasive sea squirts: A growing global problem. J Exp Mar Biol Ecol $342: 3-4$

López-Legentil S, Ruchty M, Domenech A, Turon X (2005) Life cycles and growth rates of two morphotypes of Cystodytes (Ascidiacea) in the western Mediterranean. Mar Ecol Prog Ser 296:219-228

Lowe AJ (2002) Microcosmus squamiger; a solitary ascidian introduced to southern California harbors and marinas: salinity tolerance and phylogenetic analysis. $\mathrm{M}$ Sc Thesis. California State University, Fullerton

Mack MC, D'Antonio CM (1998) Impacts of biological invasions on disturbance regimes. TREE 13:195-198 
Mack RP, Simberloff D, Lonsdale WM, Evans H, Clout M, Bazzaz FA (2000) Biotic invasions: causes, epidemology, global consequences, and control. Ecol Appl 10:689-710

Marshall DJ (2002) In situ measures of spawning synchrony and fertilization success in an intertidal, free-spawning invertebrate. Mar Ecol Prog Ser 236:113-119

Mastrototaro F, Dappiano M (2005) New record of the non-indigenous species Microcosmus squamiger (Ascidiacea: Stolidobranchia) in the harbour of Salerno (Tyrrhenian Sea, Italy). J Mar Biol Assoc UK 85: 1555.

Michaelsen VW (1927) Einige neue westaustralische Ptychobranchiate Ascidien. Zool Anz 71:193-203

Millar RH (1971) The biology of ascidians. Adv Mar Biol 9:1-100

Monniot C (1962) Les Microcosmus des cotes de France. Vie Milieu 12:397-432

Monniot C (1981) Apparition de l'ascidie Microcosmus exasperatus dans les ports Méditerranéens. Téthys 10:59-62

Monniot C (2002) Stolidobranch ascidians from the tropical western Indian Ocean. Zool J Linn Soc 135:65-120

Monniot C, Monniot F, Griffiths CL, Schleyer M (2001) South African Ascidians. Ann S Afr Mus 108:1-141

Monteiro SM, Chapman MG, Underwood AJ (2002) Patches of the ascidian Pyura stolonifera (Heller, 1878): structure of habitat and associated intertidal assemblages. J Exp Mar Biol Ecol 270:171-189

Naranjo SA, Carballo JL, García-Gómez JC (1996) Effects of environmental stress on ascidian populations in Algeciras Bay (southern Spain). Possible marine bioindicators? Mar Ecol Prog Ser 144:119-131 
Naranjo SA, García-Gómez JC (1994) Ascidias litorales del estrecho de Gibraltar: nuevas aportaciones faunísticas. Graellsia 50:57-69

Noonburg EG, Byers JE (2005) More harm than good: when invader vulnerability to predators enhances impact on native species. Ecology 86:2555-2560

Occhipinti Ambrogi A (2000) Biotic invasions in a Mediterranean Lagoon. Biol Inv 2:165-176

Osman RW, Whitlatch RB (1998) Local control of recruitment in an epifaunal community and the consequences to colonization processes. Hydrobiologia $376: 113-123$

Panagiotou M, Antoniadou C, Krestenitis Y, Chintiroglou C (2007) Stock assessment of the dominant ascidians: Microcosmus savignyi, Styela plicata and Phallusia mammillata, in Thessaloniki bay (Thermaikos gulf). Fres Env Bull 16

Papaconstantinou C (1990) The spreading of lessepsian fish migrants into the Aegean Sea (Greece). Sci Mar 54:313-316

Parker IM, Simberloff D, Lonsdale WM, Goodell K, Wonham M, Kareiva PM, Williamson MH, Von Holle B, Moyle PB, Byers JE, Goldwasser L (1999) Impact: toward a framework for understanding the ecological effects of invaders. Biol Inv 1:3-19

Pérez-Portela R, Palacín C, Duran S, Turon X (2007) Biological traits of three closely related species of Pycnoclavella (Ascidiacea) in the Western Mediterranean. Mar Biol 152:1031-1038

Piazzi L, Ceccherelli G, Cinelli F (2001) Threat to macroalgal diversity: effects of the introduced green alga Caulerpa racemosa in the Mediterranean. Mar Ecol Prog Ser 210:149-159 
Primo C, Vázquez E (2004) Zoogeography of the southern African ascidian fauna. J Biogeogr 31:1987-2009

Ranasinghe JA, Mikel TK, Velarde RG, Weisberg SB, Montagne DE, Cadien DB, Dalkey A (2005) The prevalence of non-indigenous species in southern California embayments and their effects on benthic macroinvertebrate communities. Biol Inv 7:679-686

Rilov G, Gasith A, Benayahu Y (2002) Effect of an exotic prey on the feeding pattern of a predatory snail. Mar Env Res 54:85-98

Rius M, Pascual M, Turon X (2008) Phylogeography of the widespread marine invader Microcosmus squamiger (Ascidiacea) reveals high genetic diversity of introduced populations and non-independent colonisations. Div Distrib (in press)

Rius M, Turon X, Marshall DJ (submitted) Trait-mediated effects of an invasive species in the marine environment. Oecologia

Rodriguez LF (2006) Can invasive species facilitate native species? Evidence of how, when, and why these impacts occur. Biol Inv 8:927-939

Sakai AK, Allendorf FW, Holt JS, Lodge DM, Molofsky J, With KA, Baughman S, Cabin RJ, Cohen JE, Ellstrand NC, McCauley DE, O'Neil P, Parker IM, Thompson JN, Weller SG (2001) The population biology of invasive species. Annu Rev Ecol Syst 32:305-332

Shenkar N, Loya Y (2008) The solitary ascidian Herdmania momus: native (Red Sea) versus non-indigenous (Mediterranean) populations. Biol Inv. DOI: $10.1007 / \mathrm{s} 10530-008-9217-2$

Stachowicz JJ, Fried H, Osman RW, Whitlatch RB (2002) Biodiversity, invasion resistance, and marine ecosystem function: Reconciling pattern and process. Ecology 83:2575-2590 
Streftaris N, Zenetos A (2006) Alien Marine Species in the Mediterranean - the 100

'Worst Invasives' and their Impact. Med Mar Sci 7:87-118

Svane I (1983) Ascidian reproductive patterns related to long-term population dynamics. Sarsia 68:249-255

Svane I, Lundalv T (1982) Persistence stability in ascidian populations: long-term population dynamics and reproductive pattern of Pyuna tessellata (Forbes) in Gullmarfjorden on the Swedish west coast. Sarsia 67:249-257

Thornber CS, Kinlan BP, Graham MH, Stachowicz JJ (2004) Population ecology of the invasive kelp Undaria pinnatifida in California: environmental and biological controls on demography. Mar Ecol Prog Ser 268:69-80

Turon X, Becerro MA (1992) Growth and survival of several ascidian species from the northwestern mediterranean. Mar Ecol Prog Ser 82:235-247

Turon X, Nishikawa T, Rius M (2007) Spread of Microcosmus squamiger (Ascidiacea: Pyuridae) in the Mediterranean Sea and adjacent waters. J Exp Mar Biol Ecol $342: 185-188$

Wasson K, Zabin CJ, Bedinger L, Diaz MC, Pearse JS (2001) Biological invasions of estuaries without international shipping: the importance of intraregional transport. Biol Cons 102:143-153

Whitlatch RB, Bullard SG (2007) Introduction to the Proceedings of the 1st International Invasive Sea Squirt Conference. J Exp Mar Biol Ecol 342:1-2

Yamaguchi M (1975) Growth and Reproductive Cycles of the Marine Fouling Ascidians Ciona intestinalis, Styela plicata, Botrylloides violaceus, and Leptoclinum mitsukurii at Aburatsubo-Moroiso Inlet (Central Japan). Mar Biol 29:253-259 
Zibrowius H (1991) Ongoing modification of the Mediterranean marine fauna and flora by the establishment of exotic species. Mesogée 51:83-107 
Table 1. Spearman Rank Order correlations among all variables measured on Microcosmus squamiger. ${ }^{* * *}$ indicates significant significant correlation after a Bonferroni correction.

\begin{tabular}{|c|c|c|c|c|c|c|c|}
\hline $\begin{array}{c}\text { Spearman } \\
\text { correlations }\end{array}$ & Length & Width & Height & $\begin{array}{c}\text { Intersiphonal } \\
\text { distance }\end{array}$ & Wet weight & $\begin{array}{c}\text { Mantle wet } \\
\text { weight }\end{array}$ & $\begin{array}{c}\text { Mantle dry } \\
\text { weight }\end{array}$ \\
\hline Length & 1 & $0.817^{* * *}$ & $0.853^{* * *}$ & $0.903^{* * *}$ & $0.925^{* * *}$ & $0.882^{* * *}$ & $0.896^{* * *}$ \\
\hline Width & 1 & $0.799^{* * *}$ & $0.775^{* * *}$ & $0.909^{* * *}$ & $0.877^{* * *}$ & $0.87^{* * *}$ \\
\hline Height & & 1 & $0.845^{* * *}$ & $0.921^{* * *}$ & $0.865^{* * *}$ & $0.869 * * *$ \\
\hline $\begin{array}{c}\text { Intersiphonal } \\
\text { distance }\end{array}$ & & & & 1 & $0.884^{* * *}$ & $0.826^{* * *}$ & $0.848^{* * *}$ \\
\hline $\begin{array}{c}\text { Wet weight } \\
\text { Mantle wet weight }\end{array}$ & & & & & 1 & $0.933^{* * *}$ & $0.939^{* * *}$ \\
\hline Mantle dry weight & & & & & & 1 & $0.932^{* * *}$ \\
\hline
\end{tabular}




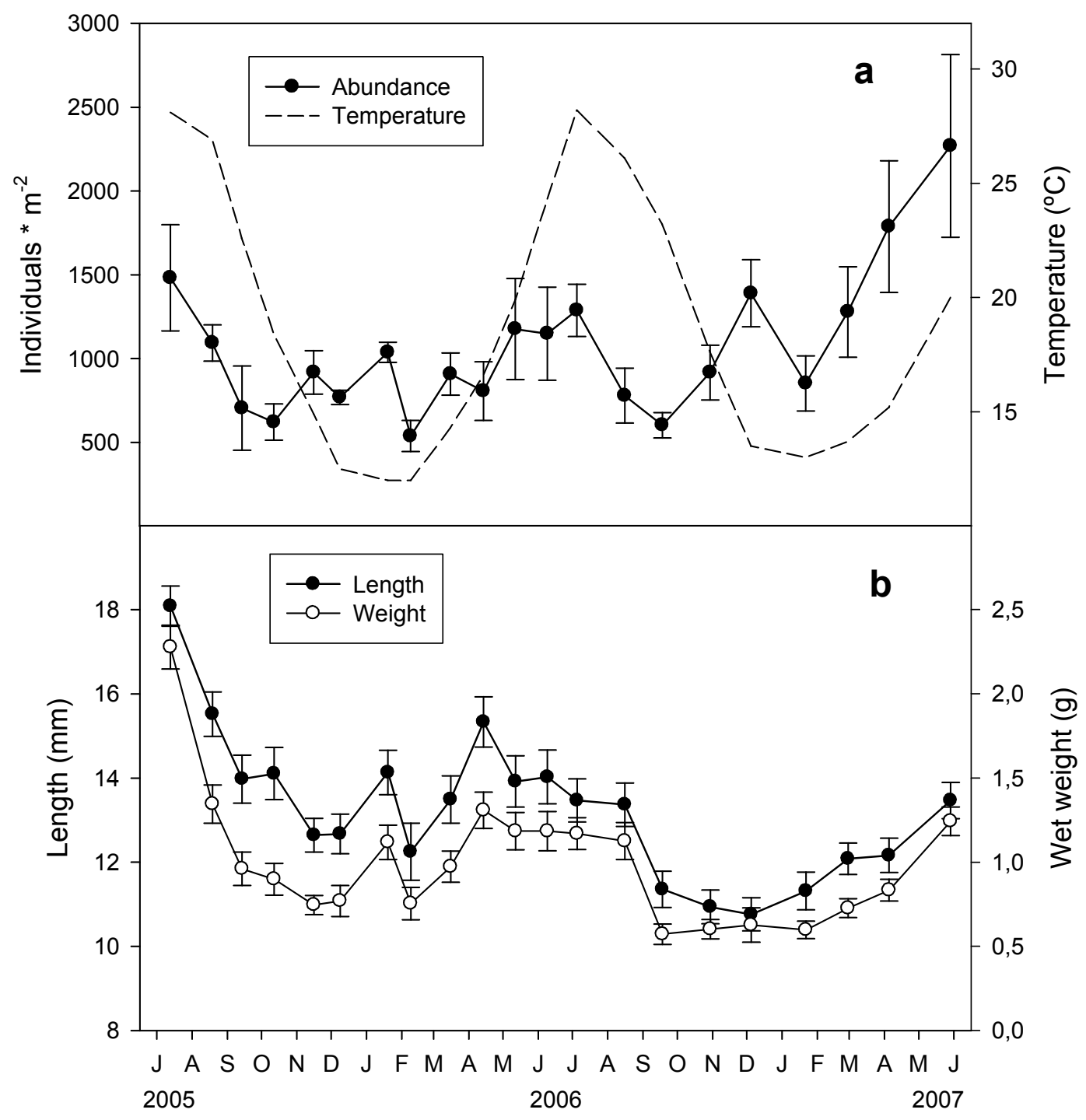

Fig 1 (a) Mean density of Microcosmus squamiger and water temperature over the study period. (b) Mean length and wet weight of Microcosmus squamiger over the study period. Vertical bars denote standard error 


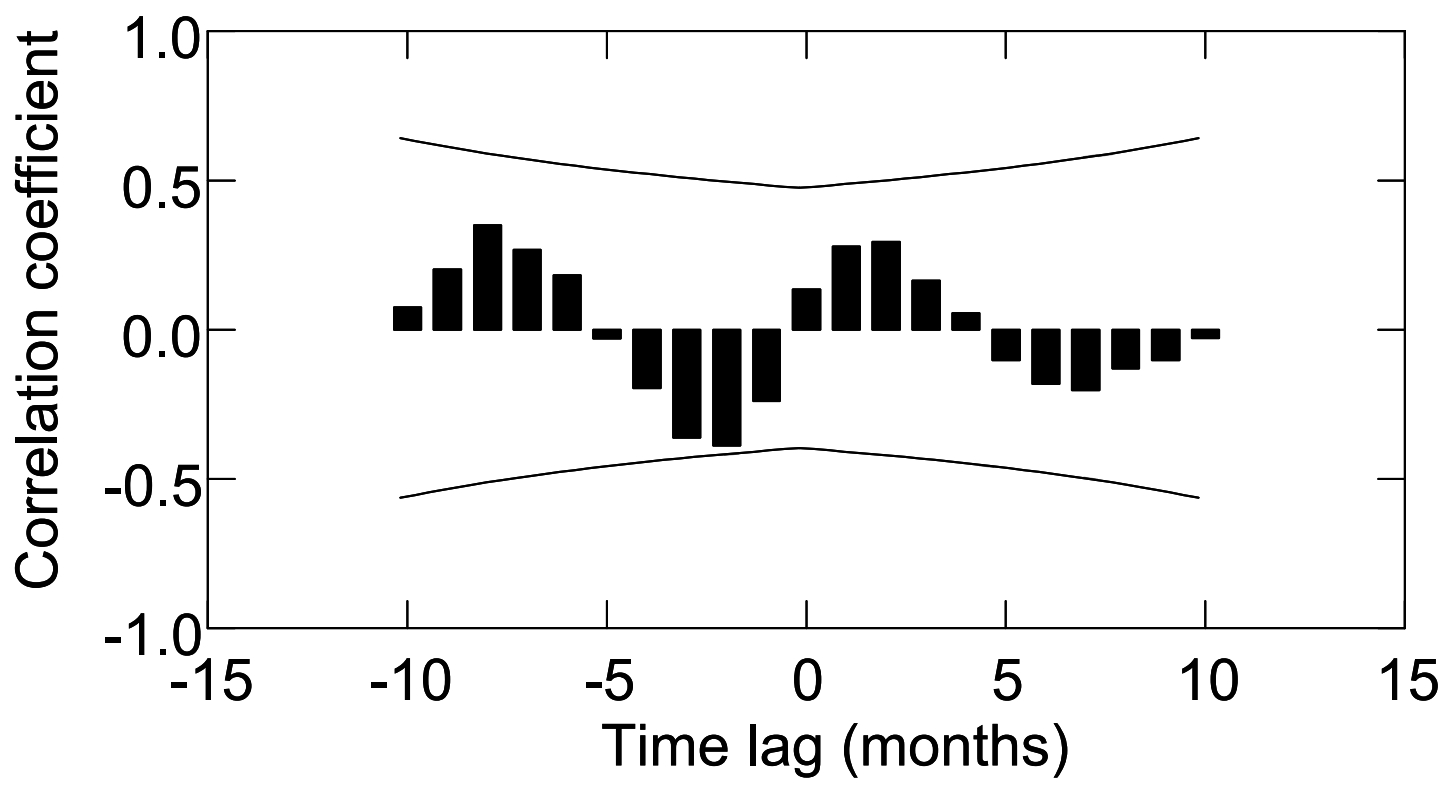

Fig. 2. Results of the cross-correlation analysis of Microcosmus squamiger abundance vs. temperature. The curved lines represent the $95 \%$ confidence interval of the correlation coefficient. 

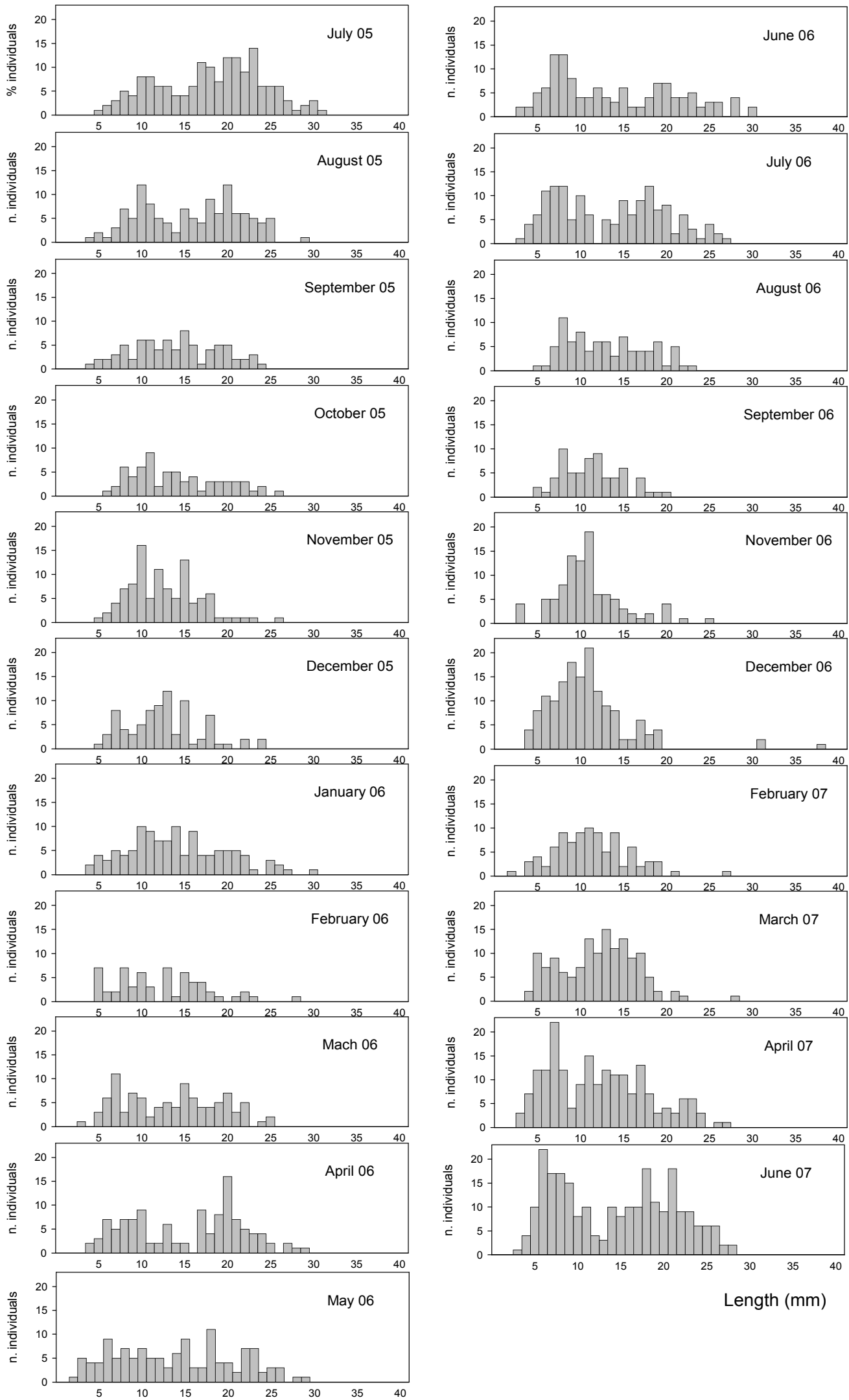

Length $(\mathrm{mm})$

Fig. 3 Size-frequency histograms of Microcosmus squamiger for each sampled month 


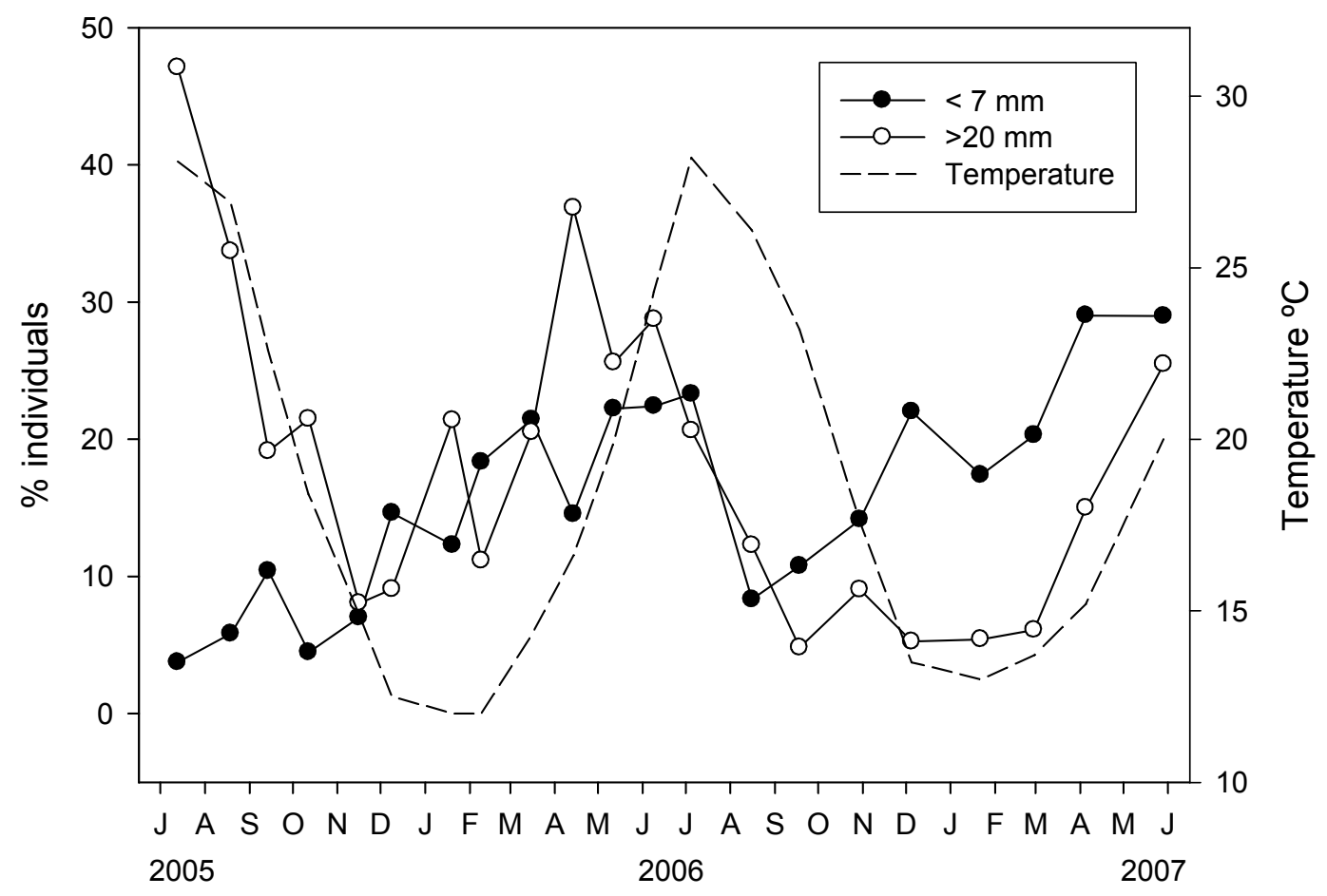

Fig. 4 Mean percentage of Microcosmus squamiger individuals larger than $20 \mathrm{~mm}$ and smaller than $7 \mathrm{~mm}$ in relation to water temperature over the study period 


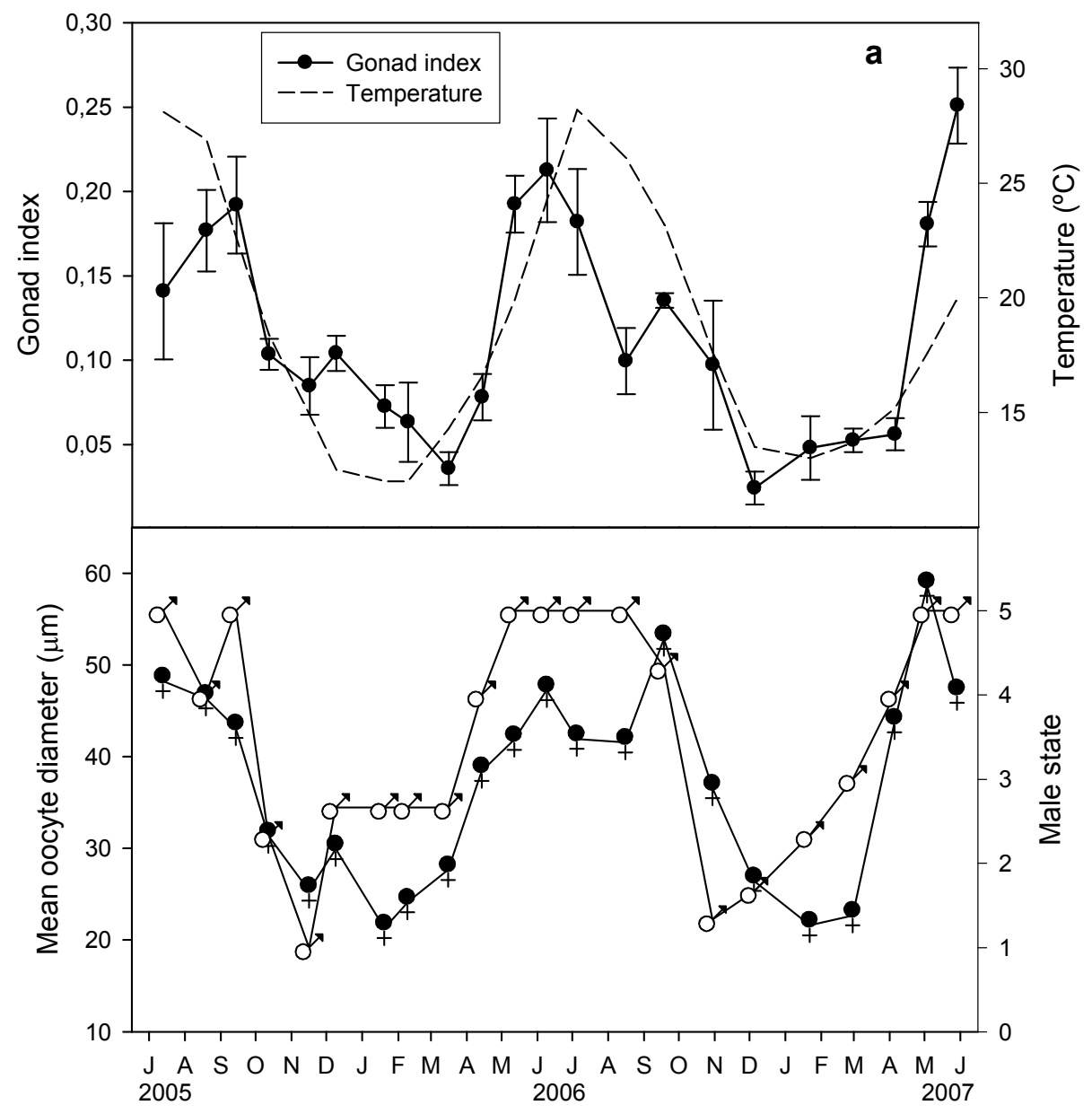

Fig. 5 Gonad cycle of Microcosmus squamiger during the study period. (a) Mean gonad index and water temperature. (b) Mean male maturity state (ð) and mean oocyte diameter $(+)$ over time 


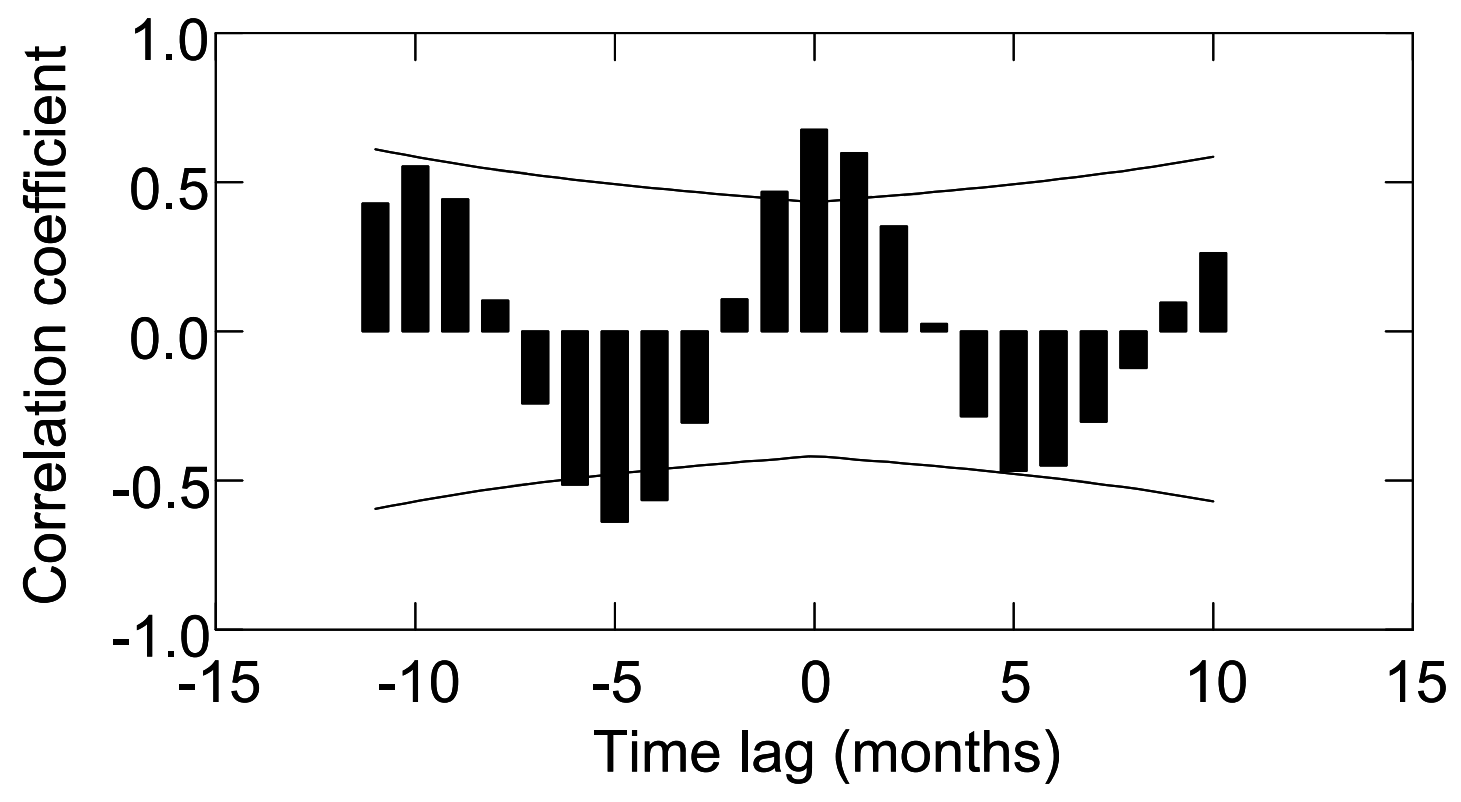

Fig. 6. Results of the cross-correlation analysis of Microcosmus squamiger gonad index vs. temperature. The curved lines represent the $95 \%$ confidence interval of the correlation coefficient. 


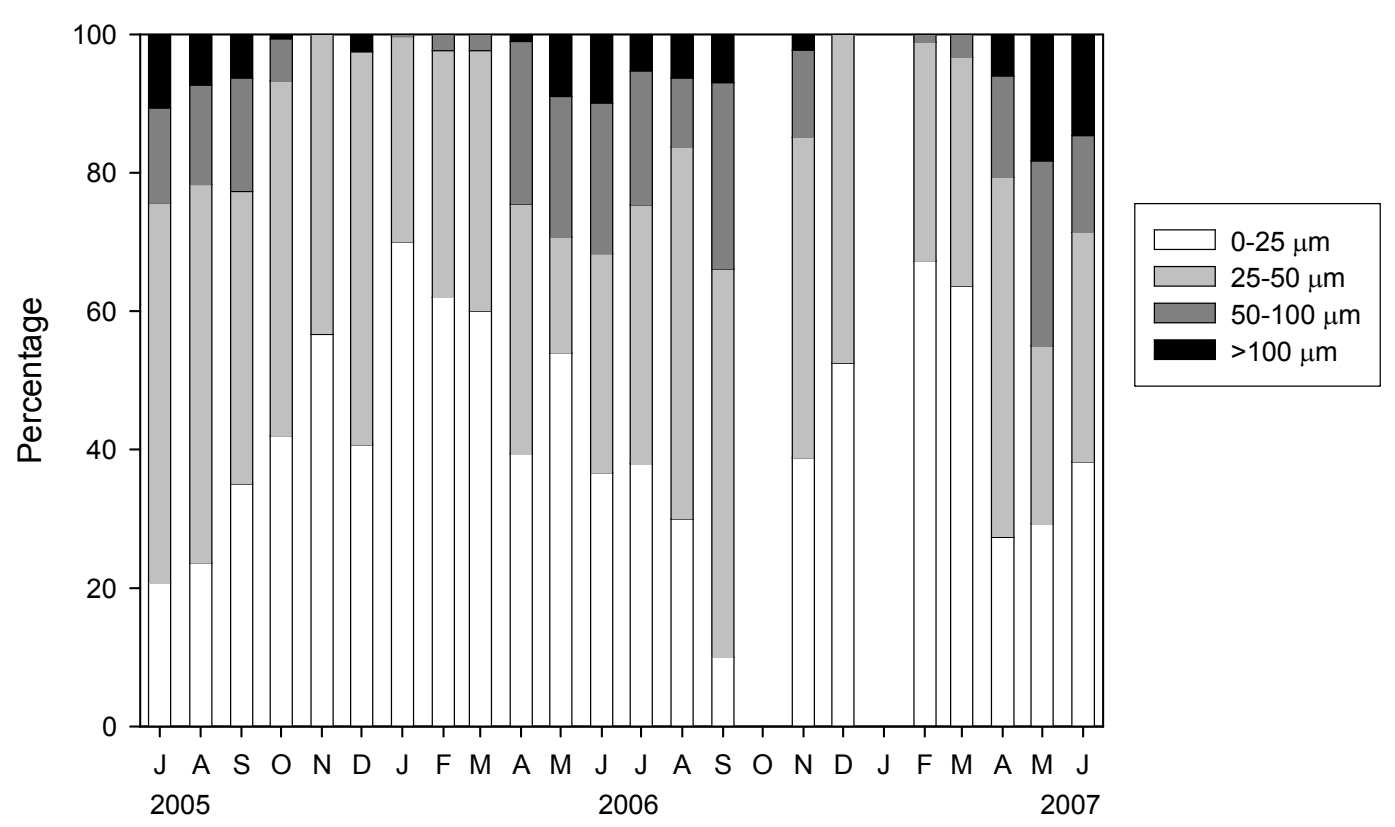

Fig. 7 Percentage of each oocyte size-class of Microcosmus squamiger over the study period 


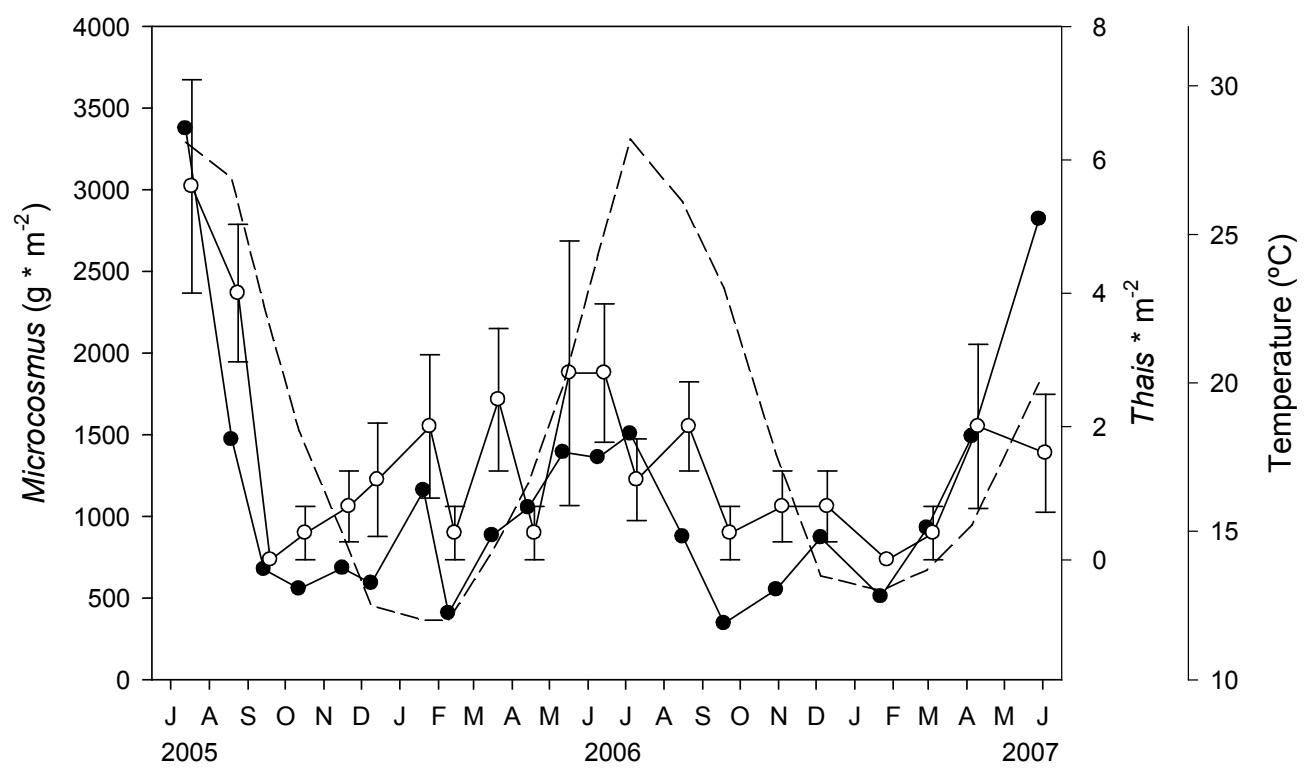

Fig. 8 Mean biomass of Microcosmus squamiger, number of Thais haemastoma and water temperature over the study period. Vertical bars denote standard error 


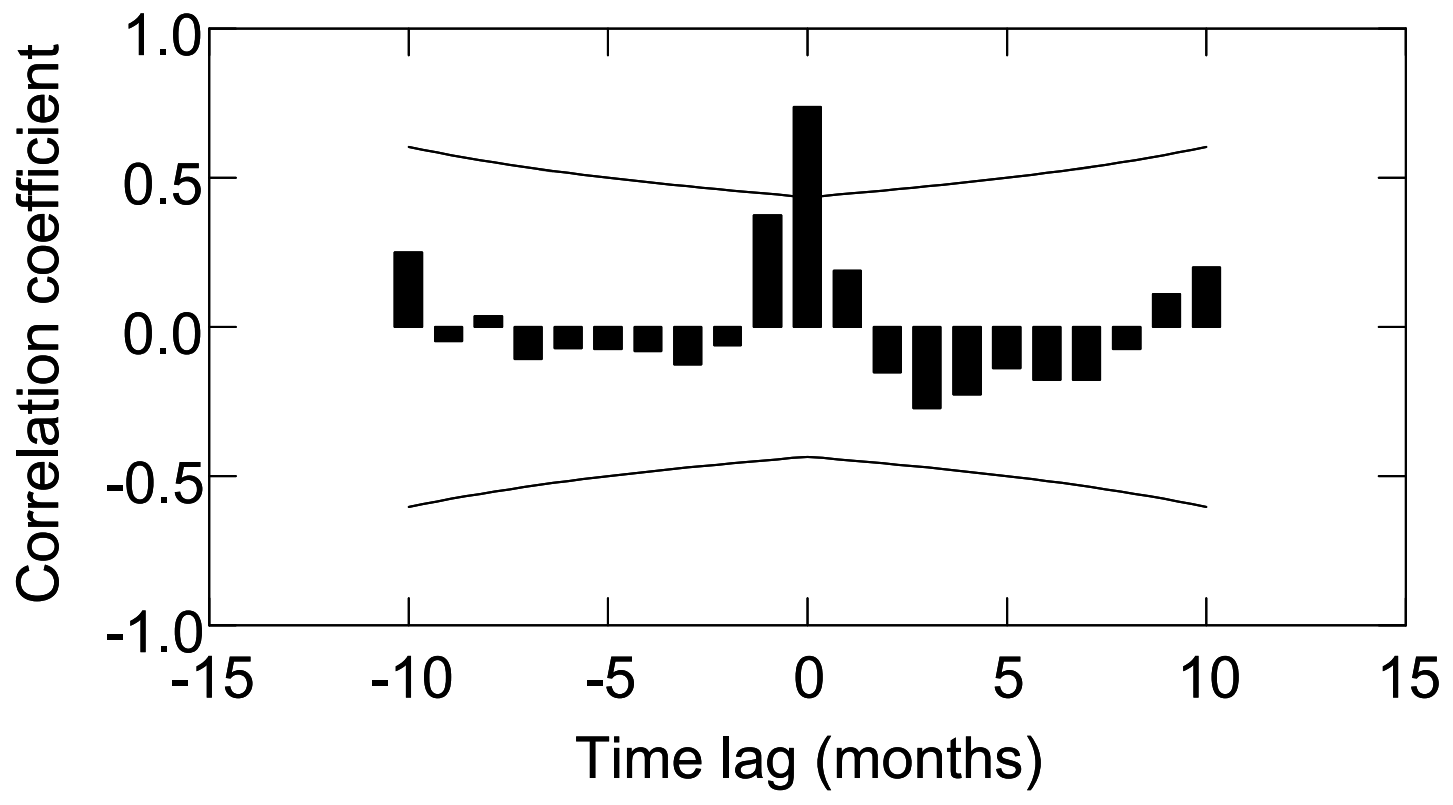

Fig. 9. Results of the cross-correlation analysis of Thais haemastoma abundance vs. Microcosmus squamiger biomass. The curved lines represent the $95 \%$ confidence interval of the correlation coefficient. 


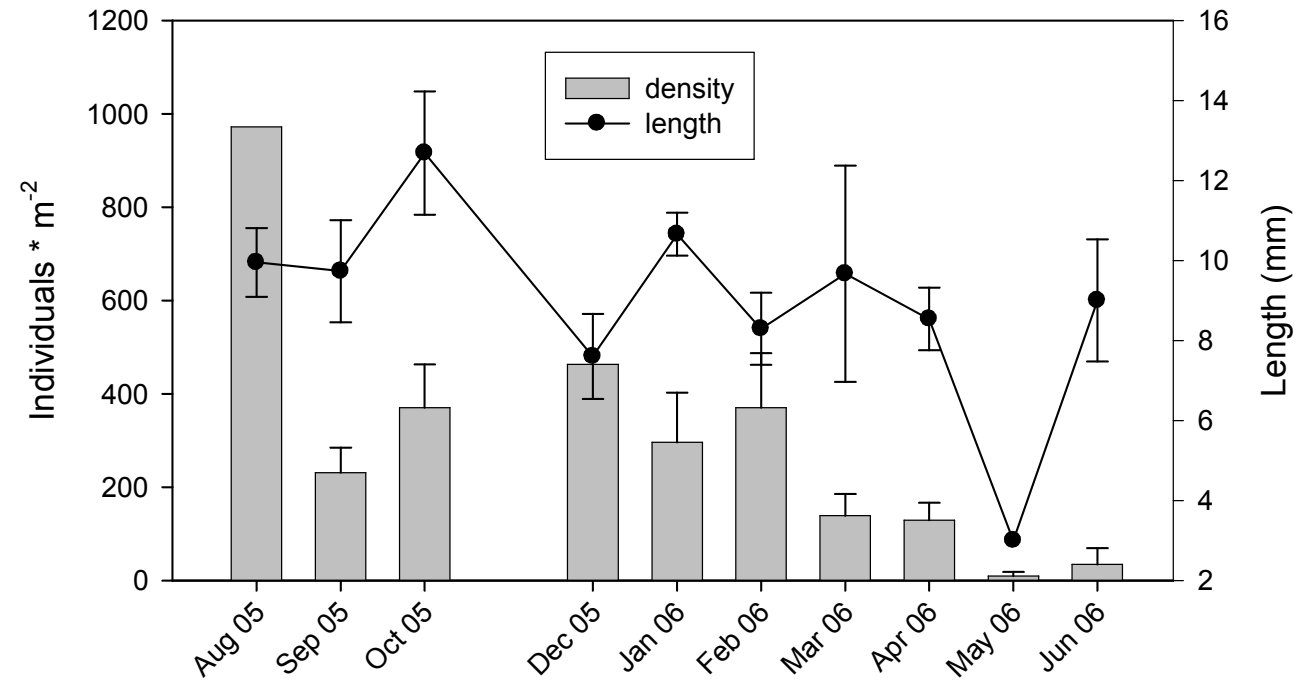

Fig. 10 Re-scrapings of the sampled plots in March 2007. Mean density of

Microcosmus squamiger and mean length of the individuals for each month. Vertical bars denote standard error 